\title{
New Jersey Women in World War II
}

Patricia Chappine

The History Press, Charleston, South Carolina, 2015. 143 pp., index. \$19.99 paper. ISBN: 9781626198210.

DOI: http://dx.doi.org/10.14713/njs.v2i1.32

This volume explores the role of New Jersey women in the World War II home front. Readers will learn a great deal from this thorough treatment of New Jersey women and their contribution to the state's war mobilization and production of weapons systems so critical to the Allied victory over the Axis powers. In the aftermath of World War II, military histories of the Second World War have concentrated on the tactical maneuvers of armies across land on three continents and major naval battles on two oceans. Subsequent histories of the war have begun to consider the importance of the mobilization and use of civilian populations for the war, productive capacity of war industries, the role of wartime propaganda in boosting civilian morale, and the incorporation of women and minorities into civilian mobilization and arms production. Patricia Chappine's study of New Jersey women is part of an emerging body of scholarship that examines not only the impact of war on women's lives, but their support of the war. Although the book does not have footnotes or endnotes, it is thoroughly researched and has a comprehensive bibliography.

The United States and England moved more quickly than Germany to mobilize the entire population irrespective of gender into the nation's concept of "total war" or more accurately described as "total mobilization for war." Joseph Goebbels' speech and radio broadcast at the Berlin Sport Palace on 18 February of 1943 following the disastrous defeat of the German Sixth Army at Stalingrad was just such a call for total mobilization. Chappine's excellent study of women in New Jersey illustrates not only the significant role of the state to the nation's war effort, but also is a great example of the rapid mobilization of the state's population for war. The 
important role women played in almost every aspect of New Jersey's home front mobilization is thoroughly discussed and researched from civil defense work to the medical care afforded wounded American soldiers and sailors.

The book is organized into eleven chapters examining the role of New Jersey women in the newly created military auxiliaries from the Women's Army Corps (WACS) stationed at Fort Hancock in Sandy Hook, Fort Monmouth, and Camp Kilmer to the Navy’s Women Accepted for Volunteer Emergency Service (WAVES) stationed in a various parts of the state like Lakehurst and Cape May. Women served as radio operators, stenographers, cryptologists, telephone operators, and photographers. New Jersey women served in the Army and Navy nursing corps during the war. Especially valuable and interesting are the testimony, memory, and reflections on their experiences of these women in oral history interview projects which Chappine's mines so effectively. Their compassion and patriotism clearly comes through in the interviews despite the physical and psychological toll of dealing with the wounded and dying: "I look back on it as time well spent, and I'm glad I did it, and I'd do it again."

The Red Cross, United Service Organization (USO), and American Women's Voluntary Services (AWVS) had established chapters to aid the soldiers and sailors stationed at the numerous army and navy installations throughout the state. Chappine's book is especially valuable for providing detailed information on the activities and locations of these organizations throughout the state. The chapter on African American is especially welcomed, for too many studies of women in World War II often neglect African American women. This study notes the role of African American women in the WACS and defense industries.

Women across the nation took jobs in defense industries and New Jersey was no exception. Women were part of the Eastern Aircraft Division of General Motors which had 
facilities in Linden, Trenton, and Bloomfield making Wildcat Fighters in Linden and Avenger torpedo bombers. Women contributed their labor to the Hercules Powder Company in Kenvil, Raritan Arsenal, and the Picatinny Arsenal. These New Jersey Rosie the Riveters tell interesting stories about the transformation of their roles brought about by war and the new labor and economic opportunities opened for them. The author observes that some of that progress made during the war was not sustained after the war as women who found non-traditional jobs in the war would not retain them in peace time. Many of the women, however, remained emboldened by the new opportunities of the war and continued to push against the barriers to full employment opportunities.

Larry A. Greene

Seton Hall University 